\title{
Usefulness of the concept of social savings and consumer surplus in studies on the impact of innovation on economic growth
}

\section{Janusz MYSZCZYSZYN \\ West Pomeranian University of Technology Szczecin, Poland}

\begin{abstract}
:
Aim: The main objective of the paper was to calculate social savings (and consumer surplus) of innovation on the example of railroads in Germany for 1985. The railways were among the most important innovations in the nineteenth century. Being aware of the limits of the social savings technique, the author included the concept of consumer surplus in his calculation
\end{abstract}

Design / Research methods: For the purpose of the research, the author used the concept of social savings proposed by Robert Fogel and consumer surplus.

Conclusions / findings: For the year 1895, social savings amounted to $2.82 \%$ (first equation) of GDP and $5.04 \%$ of GDP (second equation), taking into account elasticity of demand $(-1,38)$, social savings amounted to $1.27 \%$ of GDP and $2.18 \%$ of GDP for Germany. The result thus elicited the author referred to the social savings from railroads as made available in literature and the author's previous research. The author demonstrated that the social savings from the innovation were relatively small.

Originality / value of the article: The results of research are useful for examining the impact of innovation, such as railroads, on the level of social savings. The paper fills the gap in the Polish economic thinking on the use of counterfactual methods.

Implications of the research: The concept of social savings which takes into account demand elasticity can be applied successfully in evaluating the impact of (various) innovations on economic growth.

Limitations of the research: The weakness of the method may be the lack of knowledge about the real level of elasticity of demand for innovation, as well as determining the level of prices of an alternative good, especially if the use of innovation at the initial stage of bringing it to the market involves a relatively high price.

Keywords: Social savings, consumer surplus, elasticity of demand, innovation, rail transport.

JEL: N73, O30, R11

Contact details: Janusz Myszczyszyn, West Pomeranian University of Technology Szczecin, al. Piastów 17, 70-310 Szczecin, Poland, E-mail: jmyszczyszyn @ zut.edu.pl

Received: 15.05.2016, Revised: 24.02.2017, Revised: 30.05.2017, Revised: 20.09.2018 Accepted: 20.09.2018.

DOI: http://dx.doi.org/10.29015/cerem.288 


\section{Introduction}

The role of technological innovations in creating economic growth can hardly be overestimated. Numerous examples of technological changes can be cited, depending on the period studied, which affected both the growth rate and rising standards of living.

The development of transport, including that of railroads, was certainly crucial to building the capitalist order of the nineteenth century given that transport was what, on the one hand, determined the rapid growth of other industries of the national economy, with this rapid growth, on the other hand, calling for more efficient modes of communication.

The railroad, being one of the most important innovations during the technological revolution, has frequently been the subject of research. In this respect, the studies launched in the 1960s proved to be critical as they contributed to the emergence and development of a new paradigm, New Economic History ${ }^{1}$. In seeking to verify the long established theorems and commonly accepted truths, scholars associated with this research stream use historical statistical data in order to investigate them in-depth by employing econometric methods.

The belief that railroads, as a novel means of communication, played one of the most crucial roles in the economic development of Europe and the USA was just such commonly accepted truth (Fishlow 1965; Fremdling 1985; Voss 1960; Myszczyszyn 2013). This view was, however, altered by Fogel's work Railroads and American economic growth. Essays in econometric history (Fogel 1964).

Hence the main aims set by the present author are as follows:

- to show the usefulness or usability of the social saving measure, including consumer surplus, in the assessment of the impact of the rail sector on economic growth of the German Reich;

- to determine the level of savings in relation to the gross domestic product (GDP) for the period set by the author. Considering that two studies, those by Sympher and

\footnotetext{
${ }^{1}$ It was initiated in the 1950s by two young scholars J. Meyer and A. Conrad, and further expanded by, among others, Fogel (1962), and Fishlow (1965).
} 
Heubach, concerned with the rivalry between rail and waterway transport were available, the author analyzed the year of 1985 ;

- to compare the results produced (for the year 1985) with the author's previous findings presented in his work Wplyw kolei żelaznych na wzrost gospodarczy Niemiec (1840-1913) [The impact of railroads on German economic growth (1840-1913)] (Myszczyszyn 2013a) and with the results calculated by other authors.

Another important aim is to promote the work of new economic historians considering the fact that the achievements in the field of the paradigm mentioned earlier have been rather limited in Poland (Pomorski 1986; Matera 2015; Guzowski, Poniat 2015).

\section{Take-off and Germany's economic growth (1850-1913). Railroad development}

Germany was the last European country to embark on a path to rapid economic development (take-off) in the mid-nineteenth century. Politically divided, impoverished and backward, German nations founded, under the aegis of Prussia, German Custom Union, which manifested their economic integration. With the war against France won, they created the German Empire (1871) which competed effectively with France, England and the USA on an economic level (Myszczyszyn 2011).

The gross domestic product (GDP) expressed in constant 1913 prices grew from M 11.4 billion (1850) to 56,8 billion (1913) thus producing an average growth rate at $2.53 \%$ over $1850-1870$, while the years following Germany's unification (18731913) saw this rate at $2.75 \%$. Moreover, the GDP per capita expressed in constant 1913 prices grew from M 338 (1850) to M 874 (1913), with an average annual growth rate between the years $1850-1870$ being at $1.76 \%$, and at $1.5 \%$ throughout the years 1873-1913. Germany was at the forefront of the economic change faced by the European continent.

To return to the development of railroads, the German nations (including Prussia) were initially (in the 1830s) reluctant to involve public funds in the 
development of this mode of transport - railroads were therefore built through the private sector and local communities. It was only in the mid-nineteenth century that the government authorities began to initiate and finance new railroads on a greater scale, with the 1870 s seeing the commencement of the process to nationalize the then private railroad.

Despite the low profitability of some of the railroads (areas scarcely populated and under-developed), the annual rate of increase of new railroads across the German nations over the years $1850-1875$ was at $5.8 \%$, falling to the level of $1.83 \%$ after 1880 (Statistisches Jahrbuch für das Deutsche Reich 1880-1914). The year 1913 saw the length of the railroads at $61159 \mathrm{~km}$. What also grew quickly was the rail network coverage- in the year 1895 which the author analyzed it was $83.6 \mathrm{~km}$ railroads per thousand square kilometers, whereas in the wake of the German unification it was only 40.1 (1871) (Figure 1).

Equally interesting and further attesting to the rapid growth of the rail sector is the comparative analysis of the volume of rail freight (in million tkm) and passenger (million pkm) transport against the GDP index per capita (1913=100) (Figure 2), as well as the comparison of the GDP index per capita against the indices of rail freight and passenger transport (Figure 3). In the year 1895, the railroads had the following capacity: 26.6 billion tkm (cargo); 19.9 billion pkm (persons).

The conclusion that can be drawn easily is that one ought to contribute the greatest growth dynamics to the rail freight transport although during the initial stage of the rail network development (up to 1870) it was the passenger transport index that grew visibly faster.

The analysis cited can be seen as evidence for recognizing the rail sector as the leading one in Germany although the rate of increase as regards new railroads from the 1880 s to the outbreak of World War One was relatively low (1.1-2.3\% annually). What, however, proved to be important for the development of local railroads was the expansion of the railroad of the third order (Kleinbahn-narrow-gauge railroad). Those railroads were critical for the local transport growth, while additionally the legal regulations in place made it possible to build them at a substantially low cost, although their vast majority failed to make any profit (Myszczyszyn 2015). 
Figure 1. The development of railroads in Germany in 1850-1913

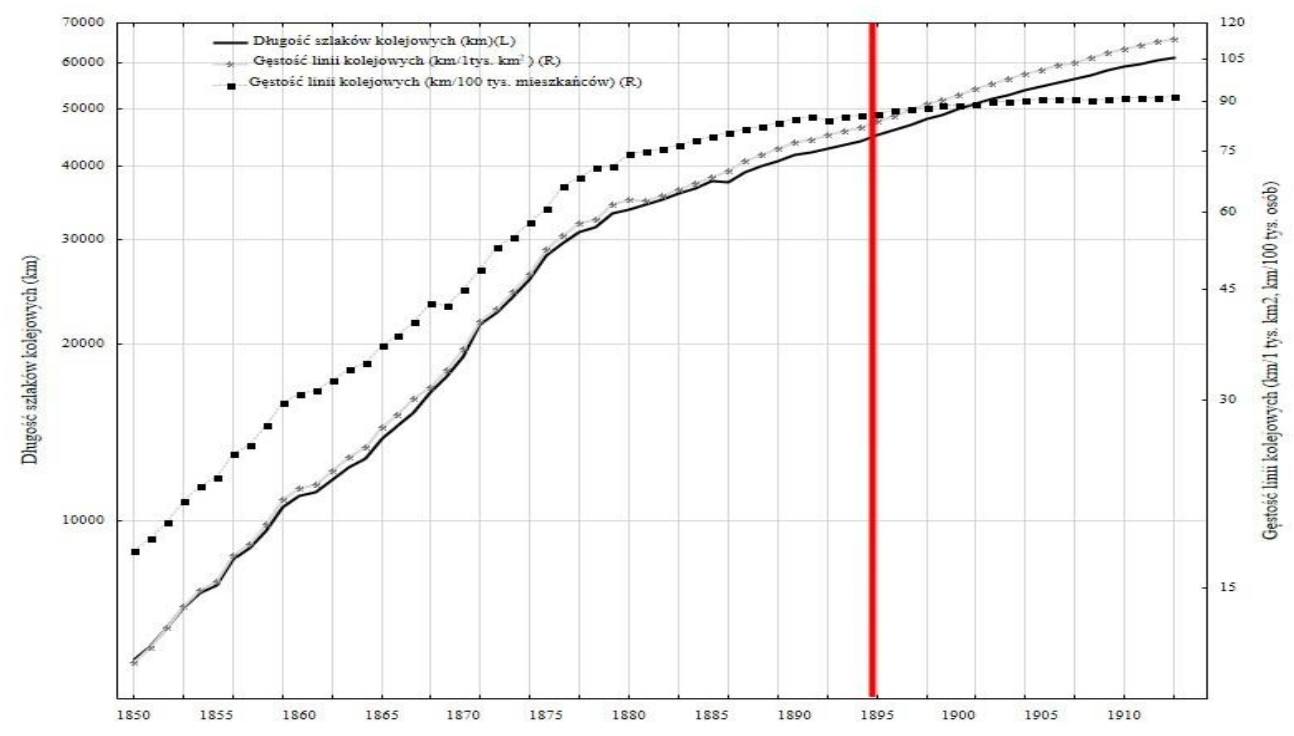

Source: author's own calculations based on: Statistisches Jahrbuch für das Deutsche Reich, 1885-1913; Hoffmann (1965).

Figure 2. German GDP index per capita $(1913=100)$ against the volume of rail passenger (million pkm) and freight (million tkm) transport

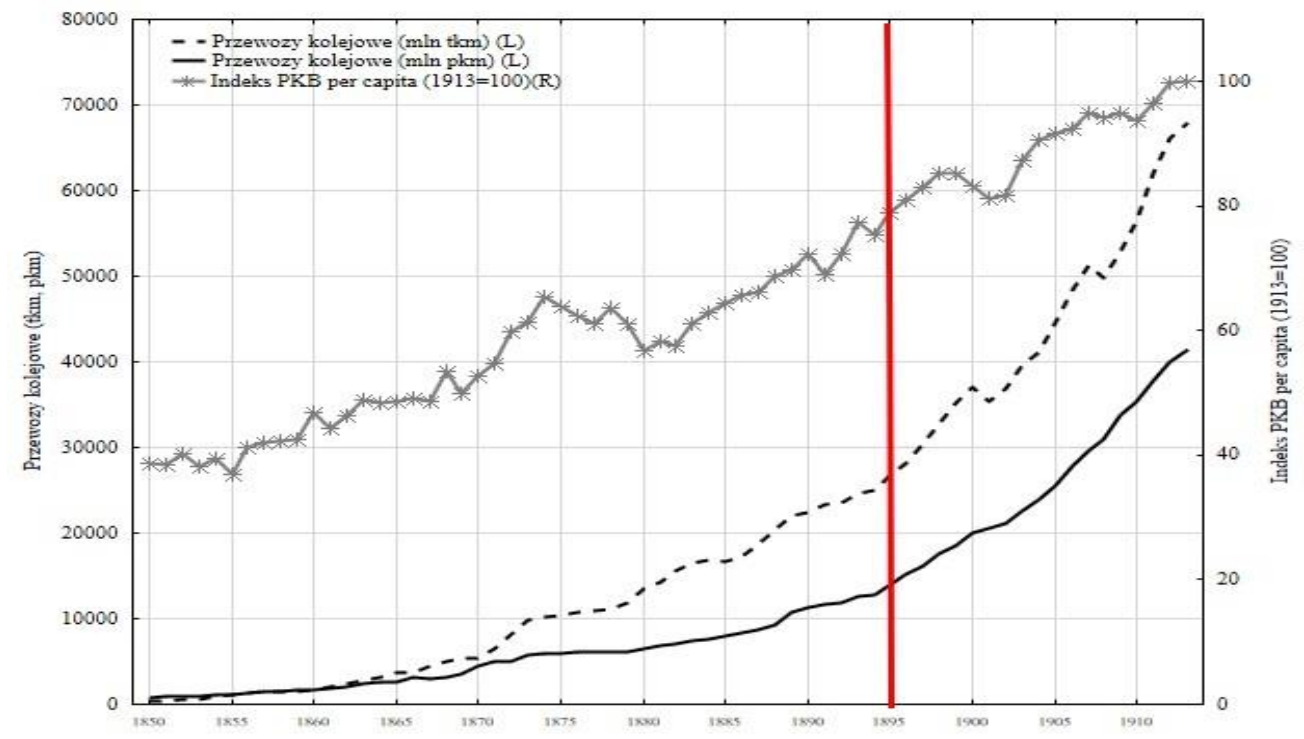

Source: author's own calculations based on: Statistisches Jahrbuch für das Deutsche Reich, 1885-1913; Hoffmann (1965); Fremdling (1985: 17-19); Myszczyszyn (2013b: 179-191). 
Figure 3. The index of the railroad length, rail passenger and freight transport (1913=100)

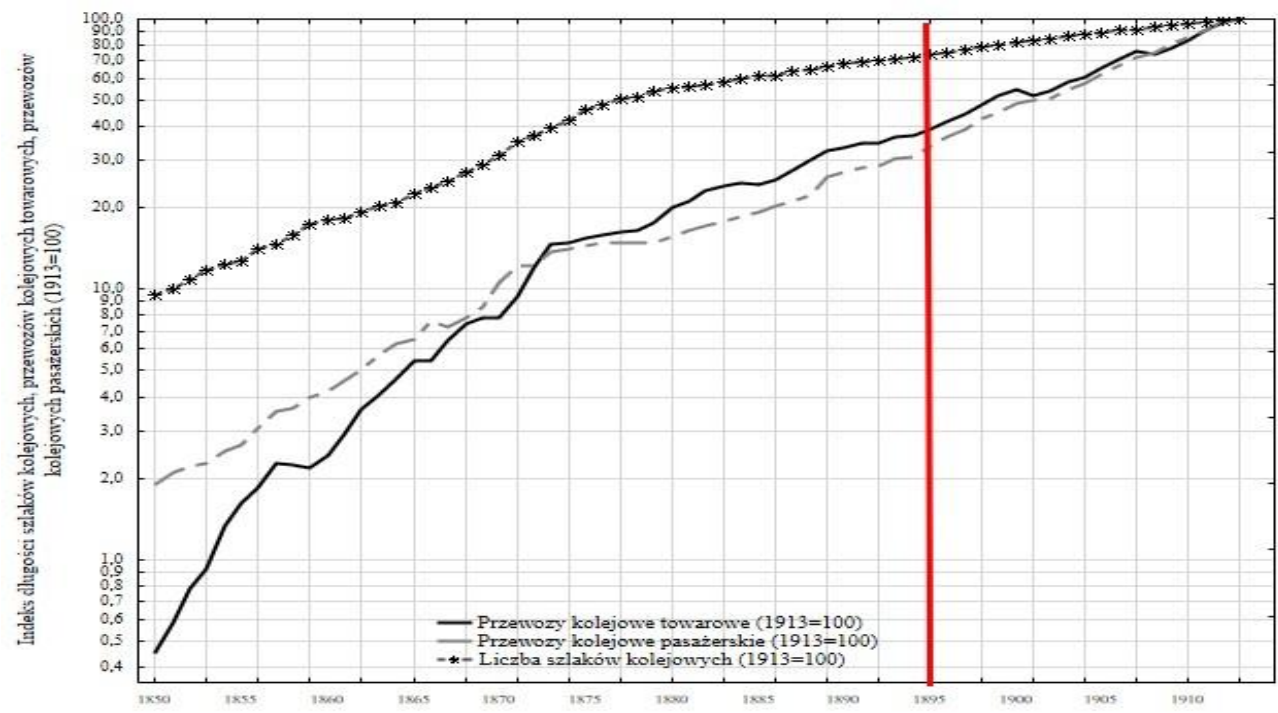

Source: author's own calculations based on: Statistisches Jahrbuch für das Deutsche Reich, 1885-1913; Hoffmann (1965); Fremdling (1985: 17-19); Myszczyszyn (2013b: 179-191).

The analysis of the above statistical data and the analysis which the author conducted at an earlier time confirm that at the end of the nineteenth century Germany was, in Europe and globally, at the forefront in railroads expansion, and consequently, in their length and coverage (Myszczyszyn 2013b).

\section{Emergence and development of the concept of social savings}

A leading representative of new economic historians, Fogel presented the concept of social savings in 1962 in a scientific paper A quantitative approach to the study of railroads in American economic growth. A report of some preliminary findings (Fogel 1962: 163-197). He elaborated on the issue of social savings in his book from 1964 Railroads and American economic growth. Essays in econometric history (Fogel 1962). In 1979 in his paper Notes on the social saving controversy, Fogel wrote "I defined the social savings of railroads in any given year as the 
difference between the actual cost of shipping goods in that year and the alternative cost of shipping exactly the same bundle of goods between exactly the same points without the railroad." (Fogel 1979: 2-3).

The social savings methodology is based on estimating the savings produced by a new technology compared to another (traditional) technology. The savings on resources is compared to the gain in real national income. Social savings tend to be expressed as a percentage of the gross domestic product (GDP), gross national product (GNP), net national product (NNP).

Figure 4. A hypothetical demand for new transport services and traditional transport as exemplified by the rail sector, taking into account rigid $\left(\mathrm{D}_{\mathrm{T}}\right)$ and elastic demand curve $\left(\mathrm{D}_{\mathrm{T} 1}\right)$

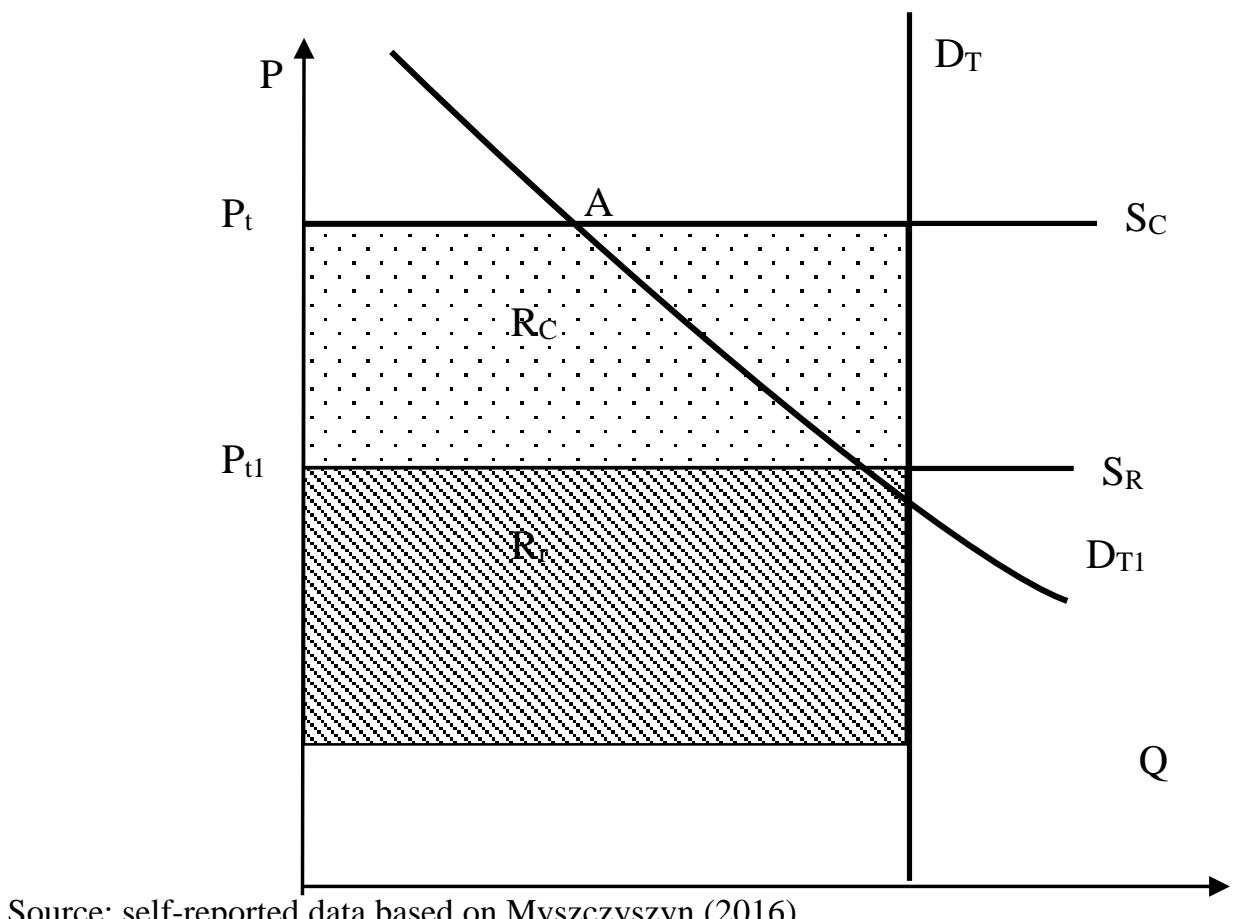

Source: self-reported data based on Myszczyszyn (2016).

The method used to calculate social savings is illustrated below, assuming that the demand curve $\mathrm{D}_{\mathrm{T}}$ is perfectly inelastic (rigid demand) and also when the demand curve is elastic $\mathrm{D}_{\mathrm{T} 1}$ (Figure 4).

where: 
$\mathrm{D}_{\mathrm{T}}$ - rigid demand for services, e.g. transport service,

$\mathrm{D}_{\mathrm{T} 1}$ - (elastic) demand for services, e.g. transport service,

$\mathrm{S}_{\mathrm{C}}$ - supply of alternative transport services (without railroads),

$\mathrm{S}_{\mathrm{R}}$ - supply of alternative transport services (including railroads),

$\mathrm{R}_{\mathrm{C}}$ - social savings from innovation,

$\mathrm{R}_{\mathrm{r}}$ - resources spent on transport (with railroads).

As O'Brien notes, counterfactual reasoning "can be used if reliable alternatives are available and which in addition have to be adequately defined" (O'Brien 1977: 23). This is why the premise of the social saving concept proposed by R. Fogel was that social savings brought about by the expansion of railroads were most frequently confronted by having them compared to waterways networks.

As Fogel assumed, the capital necessary for the rail network to expand was equal to normal profits (normal profits were equal to alternative costs). Moreover, Crafts notes that the social saving approach is also a practical method to calculate total factor productivity (Myszczyszyn 2013b: 161, 179-191).

In the social saving accounting, one defines what costs society would incur if there was no innovation, with the post-innovation demand. Hence, it can be given as:

$$
\text { Social savings }=\left(\mathrm{C}_{\mathrm{t}-1}-\mathrm{C}_{\mathrm{t}}\right) \mathrm{Q}_{\mathrm{t}}
$$

where:

$\mathrm{C}$ - marginal cost (assuming that costs are proportional to production, the marginal cost is the same as the average cost),

$\mathrm{Q}$ - total quantity,

$\mathrm{t}-1$ - pre-innovation time,

$\mathrm{t}$ - post-innovation time.

Assuming that the market is fully competitive, market prices can be viewed as the cost measure, then social savings are defined as:

Social savings $=\left(\mathrm{P}_{\mathrm{t}-1}-\mathrm{P}_{\mathrm{t}}\right) \mathrm{Q}_{\mathrm{t}}$

where:

$\mathrm{P}_{\mathrm{t}-1}=$ price of an alternative transport mode, e.g. inland waterways transport,

$\mathrm{P}_{\mathrm{t}}=$ price of rail transport,

$\mathrm{Q}_{\mathrm{t}}=$ the quantity of goods transported by rail (e.g. tkm - ton-kilometer) 
The assumption referring to the market competitiveness is deliberate since the data on costs, unlike on prices, are usually unavailable or very difficult to acquire. The only thing that needs to be recalled is that according to the microeconomic premises, prices, over a long period of time and with perfect competition, equal costs (companies make only normal profit). For rail transport, this is a very strong premise that is hardly justified in practice.

Fogel also created an upper bound estimate of social savings assuming that transport demand was perfectly inelastic.

Fogel's calculations showed that social savings of the rail sector in the USA (1890) were only at $1.8 \%$ of GDP. This finding and Fogel's theses came as a considerable surprise to the scientific community. Fogel's methodology, as a counterfactual methodology, has been used in some countries with a view to estimating the influence of railroad on economic growth. Those calculations are presented in the present author's work (Myszczyszyn 2013b). For instance, social savings from the rail sector (including freight transport) were at $4.1 \%$ of GDP in England and Wales (1859), 11\% (1890); Brazil 19-38\% (1913); France 5.8\% GDP (1872); Spain 7.5\% (1978).

However, the data cited above as regards social savings cannot be seen as clear indicators for the involvement of railroads in generating economic growth in any given country considering the following:

- the social savings calculations that are available in the literature refer to different countries, different years, and were conducted using a variety of methodologies, and, in the light of the fact that some data were unavailable, those estimates may be unreliable and so drawing clear conclusions may be flawed,

- the value of social savings may be substantially smaller if we assume that price elasticity of demand is high. In such case the falling prices, in line with the elasticity concept, lead to increased demand (and vice-versa), which is why Leunig advocates using consumer surplus for the analysis of the impact exerted by the development of technology. 
According to Fogel, the social saving methodology entails calculating savings in any period investigated while determining the difference between the actual cost of e.g. freight, passenger transport in this year and the alternative cost, e.g. using inland waterways for transporting exactly the same amount of goods, number of people. Thus, the railroads are theoretically eliminated.

The figure illustrates the demand for transport while assuming that it is either rail transport that is taken into consideration $\left(\mathrm{S}_{\mathrm{R}}\right)$ or only an alternative mode of transport $\left(\mathrm{S}_{\mathrm{C}}\right)$. In the case that is typical for the social saving concept one should determine total expenditures (revenue), that is an $\mathrm{R}_{\mathrm{C}}$ area, which would denote possible savings in the economy as a result of the rail sector development, and then to refer those savings to the GDP level.

In summing up, one should emphasize that, notwithstanding the criticism directed at the calculation of social savings, in the case of the rail sector this indicator has become a valid element in defining the effects of an innovation which in the nineteenth century the railroad expansion embodied.

\section{The consumer surplus concept}

Fogel's social saving concept faced considerable criticism. This comes as no surprise given that in the USA one of the major innovations of the nineteenth century, that is railroad, was characterized by a relatively low rate of social savings.

In the wake of Fogel's publication, Boyd and Walton (1972) questioned the advisability of calculating social savings based on the assumption that the elasticity demand coefficient was equal 0 . This implies that demand is rigid, failing to respond to price changes. In principle, one can recognize that social savings estimated in this way determine, in line with Fogel's reasoning, an upper bound estimate of savings.

The research on econometric estimates of price elasticity of demand for passenger transport which Boyd and Walton conducted after the Second World War brought them to the conclusion that this indicator was equal |1| (unit demand). Hence, consumer surplus could be called the total financial gain of all consumers who would be willing to purchase one unit of a given good at a price that is higher 
than the price of market equilibrium $P_{R}$. The exact size of this measure depends on the shape of the demand curve, which as a rule is characterized by a negative slope (Greasley, Olexey 2011; Myszczyszyn 2013b: 175-179).

This can be illustrated algebraically as follows:

$$
\Delta C S=\left(P_{t-1}-P_{t}\right) Q_{t-1}+\alpha\left(P_{t-1}-P_{t}\right)\left(Q_{t}-Q_{t-1}\right)
$$

where:

$\Delta \mathrm{CS}$ - change in consumer surplus,

$\alpha$ - a parameter determining the demand curve slope,

Q - quantity,

$\mathrm{t}$ - post-innovation time, $\mathrm{t}-1$ - pre-innovation time.

In order to determine the relationship between the social saving, and consumer surplus and the assumption that $\mathrm{Q}_{\mathrm{t}}=1$, we obtain:

$\frac{\Delta C S}{S S}=\alpha+(1-\alpha) Q_{t-1}$

With such construction of the equation there are, depending on parameter $\alpha$, three different categories, namely with the parameter assuming the following values: $\alpha>1, \alpha=1, \alpha<1$.

If $\alpha>1$, then we consider Giffen goods for which the demand curve has a positive slope (which is rather exceptional) and then the quotient $\frac{\Delta \mathrm{CS}}{\mathrm{SS}}>1$. This would mean that the fall in the price of a product is accompanied by the fall in its consumption the income effect outweighs the substitution effect. Then the quantity $Q_{t}$ multiplied by the price would be smaller than $\mathrm{Q}_{\mathrm{t}-1}$ multiplied by the price before launching the innovation. For Giffen goods, the social saving SS would be smaller than consumer surplus CS.

If $\alpha=1$, then the demand would be perfectly inelastic. This means that the social saving SS would equal the consumer surplus CS.

The third possibility, if $\alpha<1$, then $\frac{\Delta C S}{S S}<1$, which means that the social saving SS is higher than the consumer surplus CS, and this can be the most probable alternative. 
If the demand and price are normalized, in other words, $Q_{t}=P_{t}=1$, then we can assume that

$$
\mathrm{Q}=\mathrm{P}^{\mathrm{e}}
$$

where:

e - demand elasticity.

Seeking to determine consumer surplus, one can use the following equation (an increase in consumer surplus is related to $\mathrm{Q}$, while taking into account $\mathrm{P}$ ):

$$
\Delta C S=\int_{P_{t}-1}^{P_{t-1}} P^{e} d p=\frac{1}{e+1}\left(P_{t-1}^{e+1}-P_{t}^{e+1}\right)
$$

In order to determine the relationship between the change in the value of consumer surplus and social saving estimation for a fixed demand elasticity, one should present the above equation as a price and demand elasticity function, and then divide it by equation $\mathrm{SS}=\left(\mathrm{P}_{\mathrm{t}-1}-\mathrm{P}_{\mathrm{t}}\right) \mathrm{Q}_{\mathrm{t}}$. Then we will receive:

$$
\frac{\Delta C S}{S S}=\frac{P_{r}^{e+1}-1}{(e+1)\left(P_{r}-1\right)}
$$

where:

$\mathrm{P}_{\mathrm{r}}=\frac{P_{t-1}}{P_{t}}-$ the price ratio before and after innovation.

The above equations show that the size of deviation $\frac{\Delta C S}{S S}$ depends not only on the degree of elasticity of the demand straight-line curve but also on factor $\mathrm{P}_{\mathrm{r}}$.

As Fogel argued, even for a very inelastic demand curve for freight and passenger transport $(\mathrm{e}=-0,4)$, the calculations based on the assumption that elasticity equals 0 may imply that $\frac{\Delta C S}{S S}$ will change by even $46 \%$ (Fogel 1979: 11 12; Myszczyszyn 2013b).

Seeking to achieve the research objective, the present author used various degrees of demand elasticity against elasticity e=-1,38, estimated by W. Hoffmann for transport expenditures. In the case of Germany, the elasticity degree of demand for transport expenditures changed considerably over the years 1850-1913, just like the total of expenditures which households allocated for this kind of purchases. As 
Hoffmann notes, in the mid-nineteenth century, a person would spend on average 40 pf (1913 prices) on transport with those expenditures growing very fast to reach 18 M per person in 1913.

\section{Results}

Using the above assumptions, the author estimated social savings for rail freight, omitting passenger rail transport and the railroad of the third order.

Two alternatives were assumed for the rail freight - the equations 1) and 2) shown below.

In order to calculate the social savings from the first equation, the author used the source data derived from Sympher's work Die wirthschaftliche Bedeutung des Rhein-Elbe-Kanals (Sympher 1899) formulating the following equation:

1) $\mathrm{P}_{\mathrm{t}}=0.6 \mathrm{P}_{\mathrm{W}}+0.3 \mathrm{P}_{\mathrm{K}}+0.1 \mathrm{P}_{\mathrm{P}}$

where:

$\mathrm{Pw}$ - the rate for inland waterway transport determined based on the rate of average inland freight (applying the different rates for the four major waterways (river basins such as the Rhine, the Elbe, the Oder and the Vistula) which were at 1.65pf/tkm (Sympher 1899: 38-39); ${ }^{2}$

$\mathrm{P}_{\mathrm{K}}$ - the rate for inland waterway transport (canals), the rate of freight water transport was assumed to increase by $0.5 \mathrm{pf} / \mathrm{tkm}$ (Myszczyszyn 2013b);

$\mathrm{P}_{\mathrm{P}}$ - the rate for horse drawn transport (wagons) was set at 40pf/tkm.

It was assumed that the value of rail transport in 1895 was at 483 million M (Hoffman 1965). ${ }^{3}$

The results published at an earlier date referring to the first equation induced the author to formulate equation 2). To this end, the author used Heubach's study - Die Verkehrsentwicklung auf den Wasserstrassen und Eisenbahnen des Elbe=Odergebietes in dem Zeitraum von 1882-1895 (Heubach 1898).

\footnotetext{
${ }^{2}$ Author's own calculations in which the author included the estimates for the four major rivers of the Reich such as the Rhine, the Elbe, the Oder and the Vistula, as well as additional costs for water freight.

${ }^{3}$ The results from the first equation were published in Myszczyszyn (2016).
} 
Across the Oder-Elbe waterways, including the so called March route (1895), 9.2 million Mt (9 271 million tkm) were transported by rail and waterways in total, which accounted for $34.85 \%$ of the overall inland transport of the German Reich. The average length of the rail route was $117 \mathrm{~km}$, while for waterways it was $335 \mathrm{~km}$ (Heubach 1898: 24-25). The assumption was that 50\% of transport would be by using natural waterways, $30 \%$ by artificial waterways (e.g. canals), and $20 \%$ by roads using horse drawn transport (wagons).

2) $\mathrm{P}_{\mathrm{t}}=0.5 \mathrm{P}_{\mathrm{W}}+0.3 \mathrm{P}_{\mathrm{K}}+0.2 \mathrm{P}_{\mathrm{P}}$

where:

$\mathrm{Pw}$ - the rate for inland waterways transport, determined based on the rate of average inland freight (applying the different rates for two waterways (the OderElbe river basins) at $1.5 \mathrm{pf} / \mathrm{tkm}$ as the highest rate (the highest cost of brown coal freight on the Aussig-Magdeburg route), and having taken into account the fact that the waterways transport was on average $25 \%$ longer for the same distance as compared to the rail transport, it was assumed that the average cost of freight would be at 1.9pf/tkm) (Heubach 1899: 56-57, Tafel V). ${ }^{4}$

$\mathrm{P}_{\mathrm{K}}$ - the rate for inland waterways transport - artificial sections (e.g. canals), it was assumed that the freight accounted for $75 \%$ of rail freight, that is (3.06 pf), that is, $2.0 \mathrm{pf} / \mathrm{tkm}$ (Heubach 1899: Tafel V),

$\mathrm{P}_{\mathrm{P}}-$ the rate for horse drawn transport (wagons) was set at $40 \mathrm{pf} / \mathrm{tkm}$.

Table 1. Social savings of the rail sector in Germany in $\mathbf{1 8 9 5}$

\begin{tabular}{|l|l|l|}
\hline Description & Equation 1) & Equation 2) \\
\hline Rail transport (mln tkm) & 26600,00 & 26600.00 \\
\hline Alternative rate for 1 tkm (M.) & 0.055 & 0.0964 \\
\hline Value of rail transport (mln M.) & 483.00 & 813.96 \\
\hline $\begin{array}{l}\text { Value of transport as an alternative for railroads (million } \\
\text { M) }\end{array}$ & 1463.00 & 2564.24 \\
\hline Social savings (million M.) & 980.00 & 1751.24 \\
\hline Savings rate (\% GDP) & $\mathbf{2 . 8 2}$ & $\mathbf{5 . 0 4}$ \\
\hline
\end{tabular}

Source: self-reported data.

\footnotetext{
${ }^{4}$ The author's own calculations; the author took into account the estimates made for the Oder river and the Elbe, and additional costs for water freight.
} 
The value of rail transport in 1895 was calculated by multiplying the average price for rail freight $3.6 \mathrm{pf}$ by rail transport, which resulted in 813.96 million $\mathrm{M}$. The calculation results are illustrated in Table 1.

The social savings from the rail sector (freight) were at the following level:

- $2.82 \%$ of GDP according to the first equation;

- $5.04 \%$ according to the second equation.

Such results confirm that the role of railroads seen through the prism of the social savings ratio to the GDP level was relatively minor. This finding also justifies the cause and the reason prompting German researchers (Fremdling, Tilly, Pierenkemper and others) to focus rather on defining the importance of railroad as a key sector through the effects that go forwards and backwards (Vorwärtskopplungseffekte, Rückwärtskopplungseffekte), disregarding the level of investment outlays on railroad expansion at a time when waterways transport was definitely less expensive (Fremdling 1985; Pierenkemper, Tilly 2004). It should be noted that the social savings calculated by the author amounted to $2.08-2.32 \%$ of GDP in 1909 (Myszczyszyn 2013b: 175). Indeed, the rail transport had economic effects which would go "backwards" and "forwards" stimulating the development of other German industries. The development of railroads itself together with the German Custom Union, in Germany's conditions, also exerted a substantial impact on the integration and unification of the nations divided politically. Still, the success and economic development of Germany was also influenced by plenty of other factors, such as increased industrial production, chemical industry development, agricultural progress, reduced illiteracy, etc., as well as the state's involvement in the economic processes.

In the subsequent step, the author showed, using different degrees of elasticity of demand, the quantity of social savings while taking into account consumer surplus for the rail sector (Figure 5).

The savings demonstrated by the author in relation to the GDP level (1895) were only at $1.27 \%$ of GDP (assuming that the demand elasticity ratio was at the level $\mathrm{e}=$ -1.381) for the first equation and $2.18 \%$ of GDP for the second equation. It should be noted that the social savings which the author calculated for 1909 were at 1.53$1.58 \%$ of GDP (Myszczyszyn 2013b: 179). 
These calculations (and the previous ones for the year 1909) further confirm how important the elasticity of demand is for the innovation under study. Assuming that demand is inelastic, social savings may prove to be relatively high, while for elastic demand they may be considerably lower.

Assuming that demand for transport was relatively elastic, that is, the demand curve was not rigid, then consumer surplus would automatically become much lower than the social savings calculated, and for the year 1895, assuming that the demand was rigid, the surplus oscillated within the $1.27 \%-2.18 \%$ range in relation to the GDP.

Figure 5. Social savings of the rail sector in Germany taking into account consumer surplus and using different levels of demand elasticity (1895)

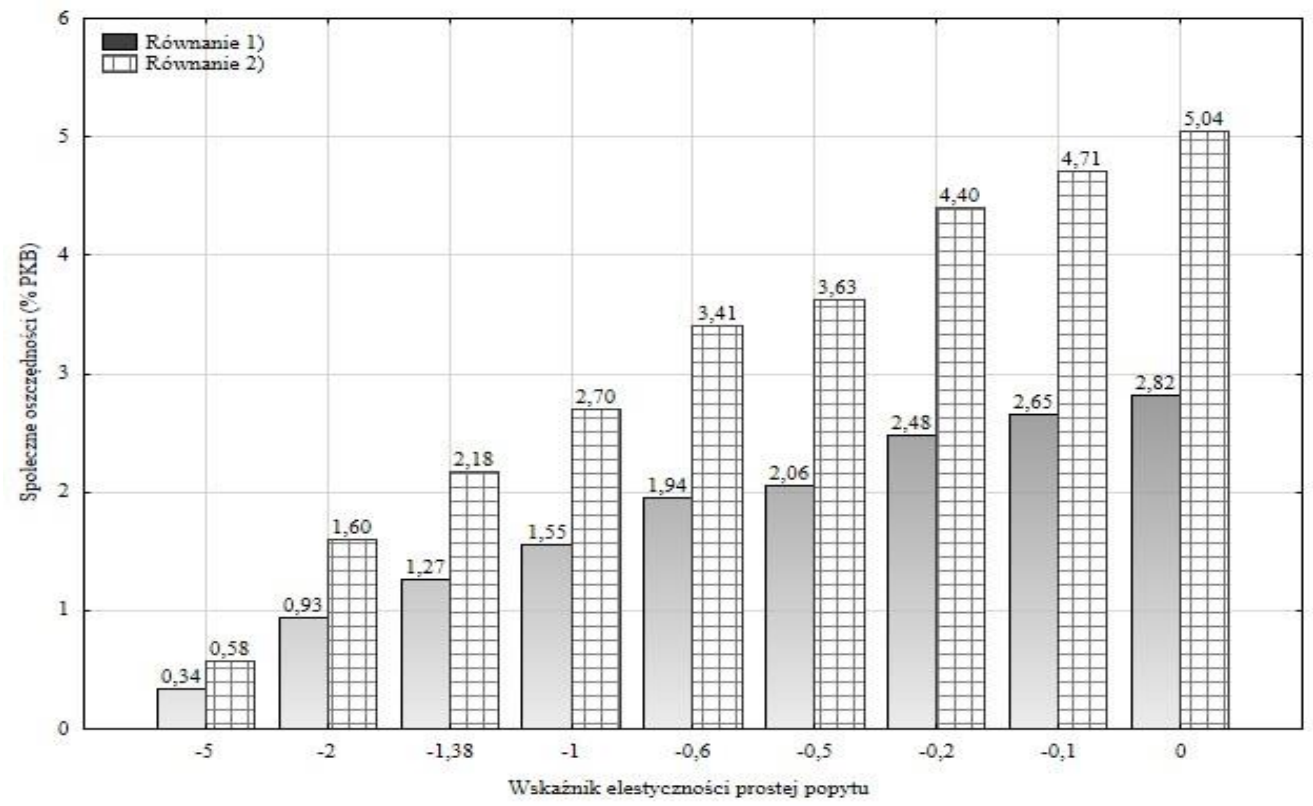

Source: self-reported data. 


\section{Summary}

The analysis of the social savings from Germany's rail sector for the year 1895 allows for drawing the following conclusions:

- the growth pace of rail transport in German nations and (later on) in the German Reich was very impressive although the waterways transport was not pushed to the sidelines of those changes. The emergence of a new transport mode coupled by a fast increase in production potential allowed for the development of trade, also stimulating the development of other industries (e.g. machine industry, iron industry). Moreover, railroads revolutionized the market of mass passenger transport and postal transport;

- the rail transport was not cheap compared to alternative modes of transport (e.g. inland waterways transport). For instance, in the case of Prussia the average fee for rail freight transport should not be lower than $2.2 \mathrm{pf} / \mathrm{tkm}$. This level assured viability of the rail transport. Sadly, the state would often bring lower fees which it justified by the higher need (cf. Grotewold 1914: 17-19, 305, 393). Still, this also yielded positive effects as the difference in the transport costs allowed for the inland transport to further develop. As Voss suggests, the development of railroads itself did not imply the reduction of transport costs. The rail transport cannot therefore be viewed as a substitute for the inland transport at the time in question. Despite the rapid development of the rail network coverage, the share of the waterways transport (1880-1913) in relation to the rail transport grew from $21.1 \%$ to $24 \%$ (Voss 1960: 62-63). However, this rapid economic growth (including the development of industry) allowed for using the (innovative) rail transport on a large scale.

- for the expansion of railroads substantial investment had to be incurred which could otherwise have been allocated for other economic activities, including the expansion of canals, river regulation, development of areas with low economic activity, and, first and foremost, constructing new road and improving the condition of the already existing hard paved roads (Myszczyszyn 2015). The most telling fact (among other things, in the context of the lack of financial resources) is the planning for over fifty years of the construction of the Rhine- 
Elbe canal. Despite Karl von Thielen's statement, who was then the Prussian minister for public construction works, that the inland waterways transport was to be seen as a partner of equal importance to railroads, the rail transport had in fact been considerably privileged (Heubach 1898: 42);

- the fee policy in rail transport was often unstable and lacking uniformity ultimately leading to the use of other alternative (cheaper) modes of transport, which inland waterways frequently represented;

- the subsequent development of wheeled transport confirmed the thesis that some portion of the railway network, even though being profitable, had to be removed in the wake of such new technology as vehicle transport which made railroads unviable. Nevertheless, the new rail sections unviable for the eastern provinces, which tended to be under-developed, brought about a new wave of economic recovery. Neither should one forget the importance of the third order railroads for the development of local markets (e.g. the Prussian province of Pomerania);

- the expansion of some of rail routes was dictated by military and political considerations, being questionable, to say the least, from an economic point of view;

- owing to economic effects (forwards and backwards), rail transport influenced the demand and development of numerous areas of national economy, delivering a transport that was more secure, on time and less dependent on the forces of nature;

- the railroad development allowed for transport in regions where waterways were developed poorly, watercourses were not navigable or their condition was such as to render bulk transport impossible. On top of that, given that the common course of rivers was in south-north, there were no transport links in east-west, and considering the shape of the German Reich border, that proved to be of particular relevance;

- in addition, rail sections between industrial centers tended to be shorter than the natural river courses, which ultimately led to having to pay more (even at a lower fee for $1 \mathrm{Mt}$ ) for the same volume of goods using the inland waterways transport. 
The analysis of social savings of railroads in Germany illustrates the relatively law value of this indicator. The results elicited confirm that alternative modes of freight transport (in this case water transport) were in many instances less expensive, which, however, does not yet mean that the emergence and expansion of railroads had no impact on economic growth and its pace, which is further corroborated by the econometric model built by the author (Myszczyszyn 2013b).

Moreover, despite its limitations, the social saving concept, (the ratio of price elasticity of demand equals 0 ) together with consumer surplus can be employed successfully in estimating the effectiveness of technological novelties supplanting previous solutions. At this point, what proves crucial is to estimate not only savings as a fraction of GDP, but also to define the degree of elasticity of the demand curve.

As the author showed, social savings can be relatively high assuming that the demand is rigid, as then it is only the upper bound estimate of the savings produced. As a result, by taking into account the level of elasticity of demand, the impact of technological novelties on economic growth may be quite radically reduced. If it turns out that demand is elastic, then consumers will respond strongly to the change in price (ceteris paribus), which can lead to a lower demand for new good and substantially reduce social savings from launching a novelty over a specific period of time.

\section{References}

Das Deutsche Eisenbahnwesen der Gegenwart (1911), vol. 1-2, Verlag von Reimar Hobbing, Berlin.

Boyd J., Walton G.M. (1972), The social savings from nineteenth century rail passenger services, „Explorations in Economic History”, vol. 9, pp. 233-254.

Crafts N. (2004), Social savings as a measure of the contribution of a new technology to economic growth, Department of Economic History London School of Economics Working Paper, no. 6, London.

Fishlow A. (1965), American railroads and the transformation of the antebellum economy, Harvard University Press, Cambridge MA.

Fishlow A. (1966), Productivity and technological change in the railroad sector, 1840-1910, in: Output, employment, and productivity in the United States after 1800, „Studies in Income and Wealth”, National Bureau of Economic Research, New York, London, pp. 583-646.

Fogel R. (1962), A quantitative approach to the study of railroads in American economic growth. A report of some preliminary findings, „Journal of Economic History”, vol. XXII no. 2, pp. 163-197. 
Fogel R. (1964), Railroads and American economic growth. Essays in econometric history, Johns Hopkins Press, Baltimore.

Fogel R. (1979), Notes on the social saving controversy, „Journal of Economic History”, vol. XXXIX no. 1 , pp. 1-54.

Foreman-Peck J. (1991), Railways and the late Victorian economic growth, in: New perspectives on the late Victorian economy. Essays in quantitative economic history, 1860-1914, Foreman-Peck J. (ed.), Cambridge University Press, Cambridge.

Fremdling R. (1985), Eisenbahnen und deutsches Wirtschaftswachstum 1840-1879. Ein Beitrag zur Entwicklungstheorie und zur Theorie der Infrastruktur, Gesellschaft für Westfälische Wirtschaftsgeschichte E.V., Dortmund.

Grotewold Ch. (1914), Die deutsche Schiffahrt in Wirtschaft und Recht, Verlag von Ferdinand Enke, Stuttgart.

Guzowski P., Poniat R. (2015), Że zaś w wieku cyfr cyframi tylko poprzeć można twierdzenie... - raz jeszcze o kondycji polskich badań nad historią gospodarczą, „Roczniki Dziejów Społecznych i Gospodarczych", vol. LXXV, pp. 289-305.

Heubach E. (1898), Die Verkehrsentwicklung auf den Wasserstraßen und Eisenbahnen des Elbe. Odergebietes in dem Zeitraum von 1882-1895, Siemenroth \& Troschel, Berlin.

Hoffmann W.G. (1965), Das Wachstum der deutschen Wirtschaft seit der Mitte des 19. Jahrhunderts, Springer-Verlag, Berlin.

Laffut M., O'Brien P.O. (ed.) (1983), Railways and the economic development of Western Europe, 1830-1914, St Martin's Press, New York.

Leunig T. (2011), Social saving, in: Economics and history. Surveys in cliometrics, Greasley D., Olexey L. (ed.), Willey-Blackwell, London.

Matera R. (2015), Kilka uwag na temat miejsca badań ilościowych w polskiej historii gospodarczej. Stan i perspektywy, „Roczniki Dziejów Społecznych i Gospodarczych”, vol. LXXV, pp. 277-288.

Myszczyszyn J. (2010), Koleje żelazne jako istotny element procesu wstępnej industrializacji państw niemieckich, „Kultura i Historia”, no. 17, http://www.kulturaihistoria.umcs.lublin.pl/archives/1757 [09.12.2018].

Myszczyszyn J. (2011), Niemiecki Związek Celny (Deutscher Zollverein) i koleje żelazne a rozwój gospodarczy Niemiec w XIX w. Próba oceny, „Kultura - Historia - Globalizacja”, no. 9, pp. 77-91.

Myszczyszyn J. (2013a), Wpływ kolei żelaznych na wzrost gospodarczy Niemiec (1840-1913), Wydawnictwo Uniwersytetu Łódzkiego, Łódź.

Myszczyszyn J. (2013b), Wykorzystanie koncepcji social savings w określeniu wpływu sektora kolejowego na wzrost gospodarczy Niemiec w początkach XX w., „Prace Naukowe Uniwersytetu Ekonomicznego we Wrocławiu", no. 305, Wydawnictwo Uniwersytetu Ekonomicznego, Wrocław. 


\section{USEFULNESS OF THE CONCEPT OF SOCIAL SAVINGS AND CONSUMER SURPLUS ...}

Myszczyszyn J. (2015), Rozbudowa infrastruktury komunikacyjnej (drogowej i kolejowej) w XIX i początkach XX wieku na przykładzie prowincji Pomorze, in: Kresy Zachodnie. Gospodarcze i społeczne znaczenie polskich kresów, Głowiński T. (ed.), Wydawnictwo Gajt, Wrocław, pp. 227-243.

Myszczyszyn J. (2016), Wykorzystanie koncepcji społecznych oszczędności i nadwyżki konsumenta w badaniach wpływu innowacji na wzrost gospodarczy na przykładzie transportu kolejowego w Niemczech, „Studia i Materiały, Miscellanea Oeconomicae”, vol. 20, no. 1.

O'Brien P. (1977), The new economic history of the railways, Billing \& Sons Ltd., Guilford, London, Worcester.

Pierenkemper T., Tilly R. (2004), The German economy during the nineteenth century, Berghahn Books, New York.

Pomorski J. (1986), Paradygmat New Economic History. Studium z teorii rozwoju nauki, Wydawnictwo UMCS, Lublin.

Statistisches Jahrbuch für das Deutsche Reich (1880-1917), Herausgegeben vom Kaiserlichen Statistischen Amt, Berlin.

Sympher L. (1899), Die wirthschaftliche Bedeutung des Rhein-Elbe-Kanals, vol. 1, Siemenroth \& Troschel, Berlin.

Voss W. (1960), Die langfristige Entwicklung des Eisenbahngüterverkehrs in Deutschland von 1880 bis 1957 in ihrer Abhängigkeit von Wachstum und Strukturwandlungen der Wirtschaft, Hamburg. 